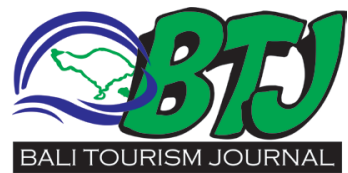

\title{
A Journey to be Eco-Tourism Destination: Bali Prepared to Shift into Electric-based Vehicle
}

\author{
Ida Bagus Komang Surya Werdiyasa ${ }^{1}$
}

\section{ABSTRACT}

Indonesia is planning to shift its astronomical number of fossilfueled vehicles to electric-based. The implementation started from Presidential Regulation Number 55 of 2019 issuance concerning the Battery Electric Vehicle Program Acceleration for Road Transportation to stop air pollution ultimately. Whereas in Bali, Governor Wayan Koster issued governor regulations number $45 \& 48$ of 2019 to serve as the legal basis for Electric Vehicle (EV) infrastructure development. To stimulate the Bali island's ecofriendly atmosphere, PT Jasamarga Bali Tol, who manages Bali Mandara Toll Road (Nusa Dua - Ngurah Rai - Benoa), launched a Public Electric Vehicle Charging Station. The Ministry of StateOwned Enterprises (BUMN) also requested PT Pertamina (Persero) to produce electric car batteries instead of only fossil fuels. For the electric vehicle battery concept, State-owned Minister Erick Thohir has negotiated with international battery manufacturers. Private companies are also involved in promoting eco-friendly vehicles, such as Grab collaborated with Bali Main Distribution Unit (UID), Bali Province Transportation Agency, PT Pegadaian, Astra Honda Motor, and Panasonic. Then, the Japanese car manufacturer, Toyota, plans to develop the Electric Vehicle Smart Mobility project in Bali to support Nusa Dua, Bali's ecotourism ecosystem. Although EV would help reduce air pollution, The Central Government must inspect the electric vehicle power source since most power plants in Indonesia are coal-fired power stations (PLTU). To solely depend on electric vehicle usage would not have a tremendous impact.
${ }^{1}$ Mediterranean Bali, Hotel \& Cruise Line Training Centre gusmang848@gmail.com

Editor:

Ida Bagus Ngurah Tri Pramana

Received : 2020-08-05 Accepted : 2020-10-25 Published: 2020-11-05

Keyword: Electric Vehicle, Regulations, Indonesia, Bali

Cite This Article: Werdiyasa, I.B.K.S. 2020. A Journey to be Eco-Tourism Destination: Bali Prepared to Shift into Electric-based Vehicle. Bali Tourism Journal (BTJ) 2020, 4(1): 44-48. D0I : 10.36675/btj.v4i1.48

\section{BACKGROUND}

Rising awareness of climate change urges countries to search for alternative ways to provide clean energy sources and eco-friendly utilities. ${ }^{1}$ Electric based vehicle is trending and receiving much attention as an answer to zero pollution vehicles demand. ${ }^{2}$ Indonesia is planning to shift its astronomical number of fossil-fueled vehicles to electric-based. The implementation started from Presidential Regulation Number 55 of 2019 issuance concerning the Battery Electric Vehicle Program Acceleration for Road Transportation to stop air pollution ultimately. Whereas in Bali, Governor Wayan Koster issued governor regulations regarding clean energy usage and battery-based electric vehicles. The action is in line with the Central Government's instructions to assign Jakarta and Bali as pilot projects for electric vehicles $(\mathrm{EV}) .^{3}$ The rules are outlined in Governor Act Number. 48 of 2019 concerning the Use of Battery-Based Electric Vehicles, which consists of 17 chapters and 25 articles. Besides, there is also Act number 45 of 2019 regarding Bali Clean Energy, which consists of 11 chapters and 33 articles. Through these Governor acts, Bali's energy needs would be directed to be independent and sustainable.
Furthermore, the acts also regulate green buildings (zero energy buildings) development based on traditional Balinese architecture and tropical area characteristics. It is expected that the building on Bali would lean towards a photovoltaic power station, with water consumption efficiency.

\section{A DREAM TO BE AN ECO-FRIENDLY TOURISM DESTINATION}

The Bali Governor acts number 45 \& 48 of 2019 serve as the legal foundations for EV infrastructure development. Simultaneously, to encourage people to switch their preferences to use EV. It is urgently required since the island's air quality is deteriorating over time. A recent publication by IQAir dated 3 July 2020, as cited by wartaekonomi, showed Ubud and Badung regency had the worst air quality among Indonesia's regions. Vehicle pollution was reckoned as the main factor to cause such perilous conditions. ${ }^{4}$ Despite air pollution, countless numbers of private vehicles also positively contributed to noise pollution. Some parties were concerned it might affect the Bali tourism sector in the future. ${ }^{5}$

Governor Koster admitted that those regulations were meant to support the tourism sector by 


\section{ENERGY SOURCES}

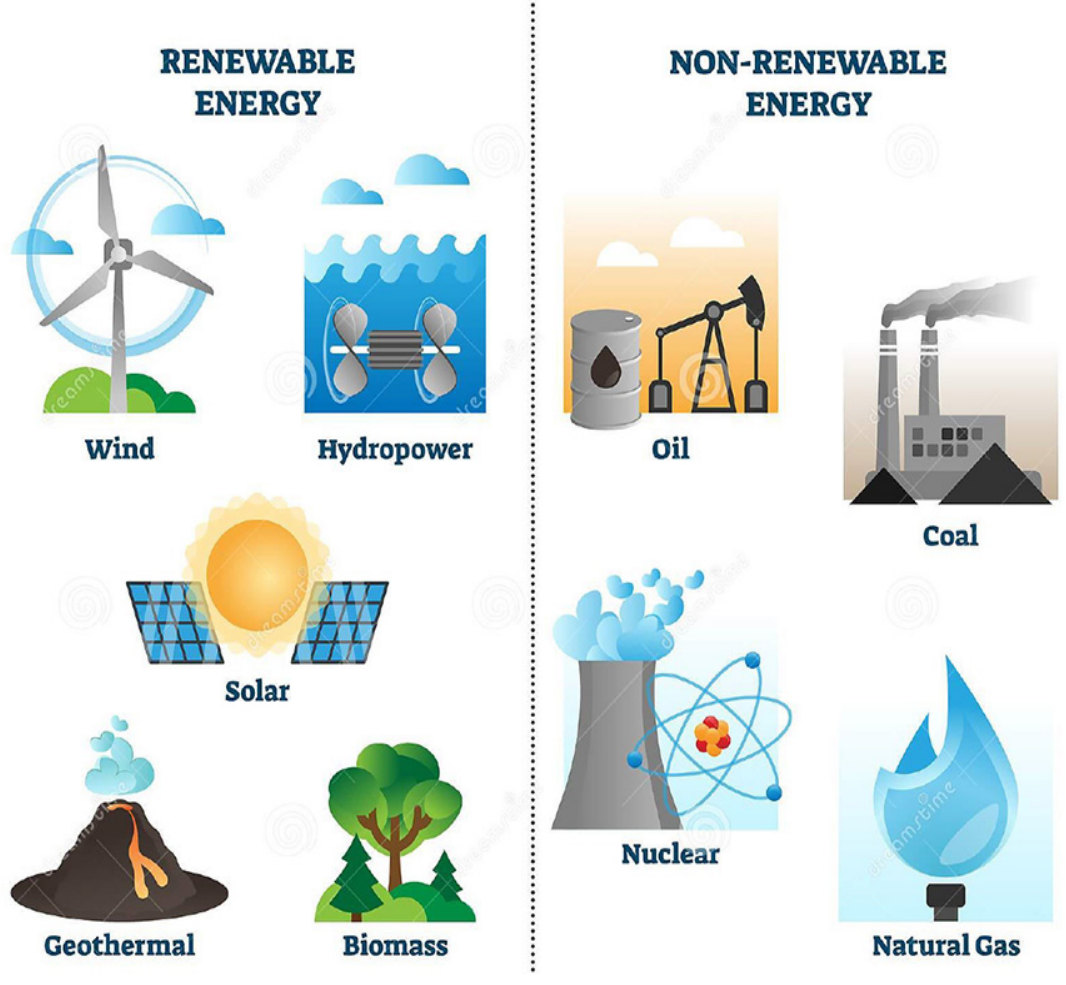

Figure 1. Illustration of Renewable and Non-Renewable Energy Sources. ${ }^{6}$

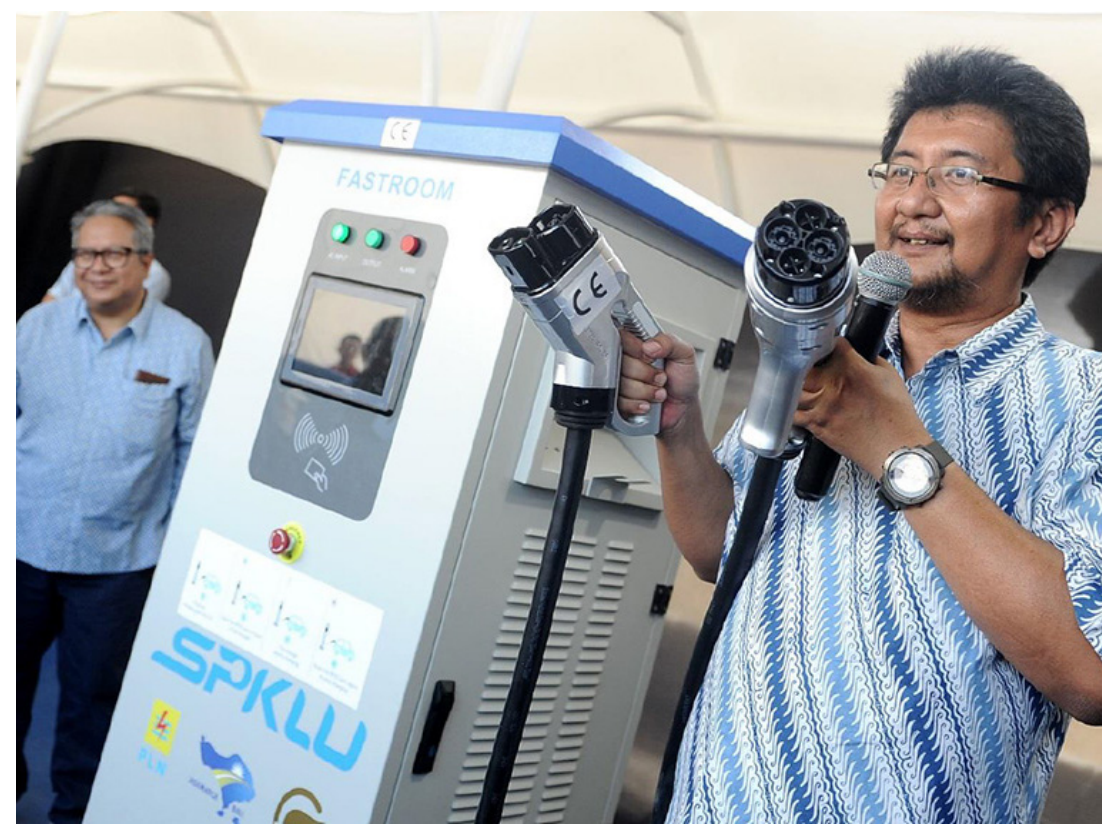

Figure 2. To stimulate the Bali island's eco-friendly atmosphere, PT Jasamarga Bali Tol, who manages Bali Mandara Toll Road (Nusa Dua - Ngurah Rai - Benoa), launched a Public Electric Vehicle Charging Station on 28 January 2020. It was a collaborative project with the State Electricity Company (PLN) and PT. Opintech Djojo Indo to support EV migration and the Green toll road concept. ${ }^{10}$ gradually switching Bali into an eco-friendly tourism destination. Bali is expected to find an eco-friendly energy source that is abundant in Indonesian territory. He emphasized the provision, utilization and development of Clean Energy in Bali would indeed be focused on Renewable Energy Sources. For instance, to generate electricity, it can be produced by renewable energy sources such as Solar, Wind, Hydro, Tidal, Geothermal and Biomass. ${ }^{7}$ On Sunday, 26 July 2020, the Governor confirmed regarding provincial plan to promote Jembrana regency as an electric vehicle industry center. In addition to an electric vehicle factory, a solar power plant (PLTS) industry would be built in a few years. Other infrastructure projects that would be conducted in Jembrana Regency, such as Public High School establishment, Denpasar - Gilimanuk toll road construction \& project to erect electric vehicle factory. According to Koster, the plan to build an electric vehicle factory had entered the feasibility study process. Meanwhile, groundbreaking construction for the Toll Road is going to start in March $2021 .{ }^{8}$

\section{STATE ENTERPRISES SUPPORT}

Meanwhile, to stimulate the Bali island's ecofriendly atmosphere, PT Jasamarga Bali Tol, who manages Bali Mandara Toll Road (Nusa Dua Ngurah Rai - Benoa), launched a Public Electric Vehicle Charging Station on 28 January 2020. It was a collaborative project with the State Electricity Company (PLN) and PT. Opintech Djojo Indo to support EV migration and the Green toll road concept. The site is located at JBT Section Pool, in Bali Mandara toll road. The PLN, as a partner, also has built seventeen power stations spread across Jakarta, Tangerang, Bandung, and Bali. According to them, although many stations were established, there were only a few EV users; thus, most of the stations were either idled or unemployed. Nevertheless, PLN keeps showing their support through many alternative ways. The recent promo was by providing up to $30 \%$ of electricity tariff discounts for EV users. Despite no fuel incentives for electric vehicle users, the Electric state agency showed their readiness to provide a discount on electricity fees up to $30 \%$. President Director of the state electricity company, Zulkifli Zaini, said the user would receive power discounts from $10 \mathrm{pm}$ to 4 am local time. He believed the number of $\mathrm{EV}$ owners in Indonesia would increase over time. ${ }^{9}$

Jasamarga Bali Toll President Director Enkky Sasono revealed, currently, Bali only has one charging station. He admitted only a few electric vehicle users on the island, as well as its supporting 


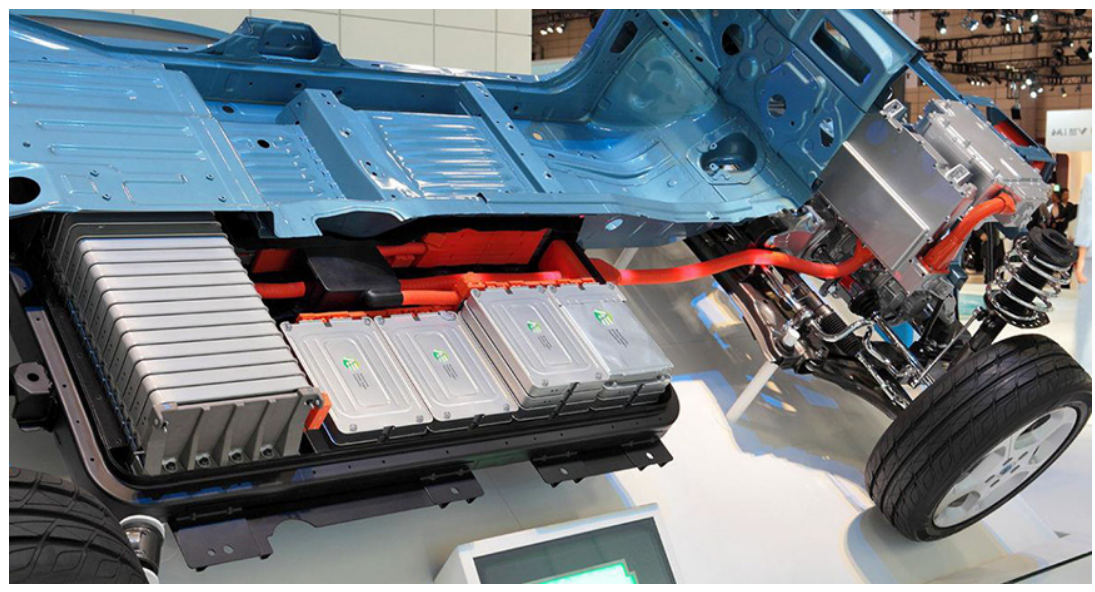

Figure 3. Image of Nissan's Electric Car Batteries

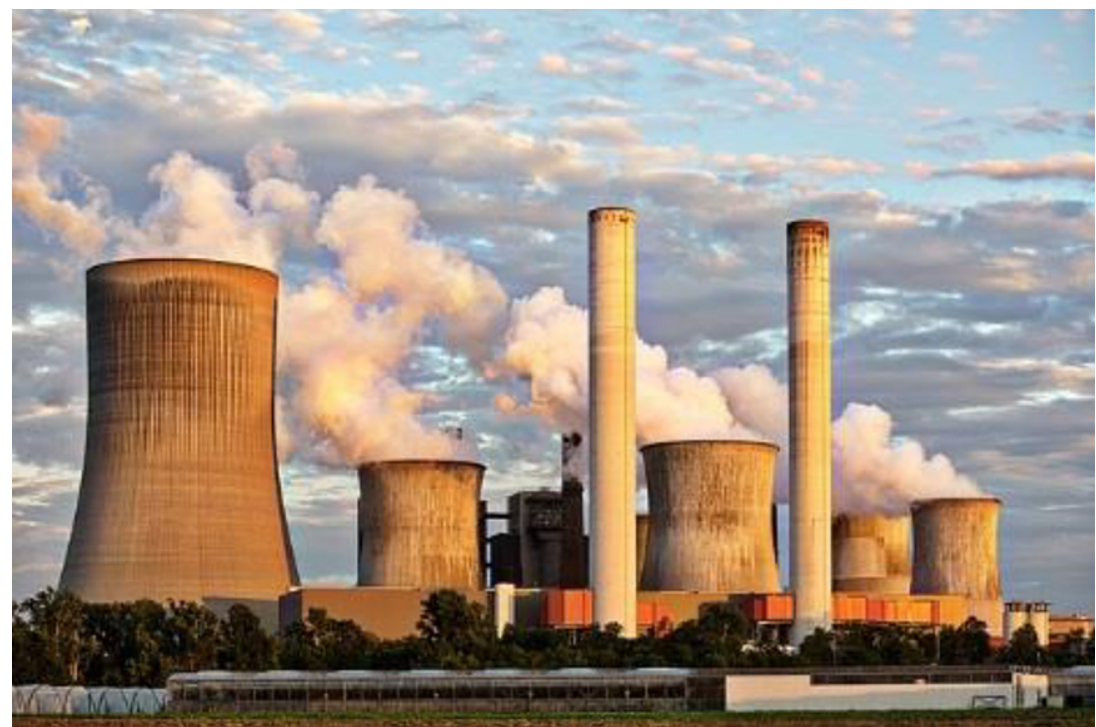

Figure 4. Hitherto, most power plants in Indonesia are coal-fired power stations (PLTU). As for its emission factor, in the Java-Bali system, the emission factor reaches 0.8-0.9 tons of carbon dioxide per megawatt-hour (MWh). ${ }^{19}$

station. Soon, He expected other stations could be built in all Bali Mandara Toll Road entrances. The construction of the charging station was a concrete milestone of Government support towards the electric vehicle shift. Shortly after being inaugurated on Tuesday (28/1/2020), the charging station received countless appreciation from the electric vehicles community. Although electric vehicles in Bali only counted fifty units, the charging station presence is considered nifty by the electric vehicle users. They argued electric vehicles are significantly saved in cost and covering a longer distance. For a 100 percent electric battery capacity, it would only cost IDR 70,000. Then it could power up the vehicle to cover 450 kilometers distance. Also, Jasamarga Bali Toll will collaborate with EV users; thus, the charging station can be maximally utilized. ${ }^{11}$ The Company also claimed to develop new environmentally-friendly energy sources such as a solar plant that would be installed along the Bali Mandara Toll Roadside. ${ }^{12}$

Hitherto, the regulations to boost electric vehicle shifting are Presidential Regulation Number 55 of 2019 concerning the Battery Electric Vehicle Program Acceleration for Road Transportation, Bali Governor Regulation (Pergub) Number 45 of 2019 concerning Bali Clean Energy and Bali Governor Regulation Number 48 of 2019 concerning the Use of Battery-Based Electric Motor Vehicles. Through Coordinating Ministry for Maritime Affairs and Investment, the Central Government ensured that battery-based electric vehicle projects would be carried on amidst of COVID-19 pandemic. Whereas, Special Staff of the Minister of BUMN Arya Sinulingga, on Tuesday 29 September 2020, revealed the Ministry of State-Owned Enterprises (BUMN) had requested PT Pertamina (Persero) to produce electric car batteries instead of only fossil fuels. They were also requested to calculate their fossil fuel reserves to ensure their supplies before ultimately shifting into electric battery suppliers in the future. State-owned Minister Erick Thohir has negotiated with battery manufacturers from South Korea and China for the electric vehicle battery concept. Then, they would also contact the international electric battery manufacturer, Tesla. ${ }^{13}$

Acting Deputy for Infrastructure and Transportation of the Coordinating Ministry for Maritime Affairs and Investment (Kemenkomarves) Ayodhia Kalake explained two critical reasons to encourage electric use and construction vehicle factories in Indonesia. The first reason was the high subsidies cost for fossil-based fuel, then fossil-fuel is scientifically proven to impact the environment in the long run negatively. Meanwhile, she revealed, Indonesia car sales in 2019 had reached 1.03 million units with a total investment of IDR 92.87 billion. The figure assured Indonesia as a potential market; thus, she expected the data would invite many investors to build EV factories in Indonesia. From the financing side, several ministries and the Bank of Indonesia (BI) also collaborated in providing benefits for EV customers. One significant proof is a zero percent down payment for purchasing environmentally-friendly vehicles. ${ }^{15,16}$

\section{PRIVATE COMPANIES PARTICIPATION}

On Thursday, 26 November 2020, Grab launched thirty electric motorbikes and Public Electric Vehicle Battery Exchange Stations (SPBKLU) at seven points spread across Bali. The project was a collaborative program with Bali Main Distribution 
Unit (UID), Bali Province Transportation Agency, PT Pegadaian, Astra Honda Motor, and Panasonic. The occasion was meant to support Bali Governor Regulation Number 45 and 48 of 2019 concerning Clean Energy and Battery-Based Electric Vehicles to create environmentally friendly traffic and transportation. Besides, the technology also implements Presidential Decree Number 55 of 2019 concerning socializing EV in Indonesia. Governor of Bali I Wayan Koster appreciated the EV launching event. According to him, the electric-based vehicle was an implementation of the Bali development vision to achieve Nangun Sat Kerthi Loka Bali. He believed that if other parties would follow such an occasion, a dream to reduce carbon emission by twenty-nine percent by 2030 is achievable. Furthermore, Koster hoped that electric motorbikes could significantly contribute to making Bali's nature free of pollution. ${ }^{17}$

Besides Grab, Japanese car manufacturer Toyota plans to develop the Electric Vehicle Smart Mobility project in Bali to support Nusa Dua, Bali's ecotourism ecosystem. Deputy for the Coordination of International Economic Cooperation of the Coordinating Ministry for the Economy, Rizal Affandi Lukman, said that in the early stages of developing electric cars, a shuttle service from the airport to tourist hotels would be introduced. Also, one to two passengers-vehicle would be available for rent as well as car-sharing facilities. The vehicle would be marketed to the foreigner and domestic tourists. Marketing Director of PT Toyota Astra Motor (TAM) Anton Jimmy Suwandy shared his opinion that ecotourism's primary target is to introduce electrification technology. Mostly to promote and to test several electric car models that have been sold. Further, Anton claimed Toyota would provide electric cars and its supporting infrastructure, a charging station. ${ }^{18}$

\section{EV EFFECTIVENESS IN FIGHTING AIR POLLUTION}

According to the Executive Director of the Institute for Essential Services Reform (IESR) Fabby Tumiwa, ideally, electricity for charging electric vehicles should be supplied from clean and renewable energy power plants. In this way, efforts to reduce air pollution and fuel dependence can be realized. The Central Government must attentively inspect the source of the electric vehicle power source. Hitherto, most power plants in Indonesia are coal-fired power stations (PLTU). As for its emission factor, in the Java-Bali system, the emission factor reaches 0.8-0.9 tons of carbon dioxide per megawatt-hour (MWh). The figure is estimated to increase as the number of PLTU development projects in Indonesia increases overtime. To solely depend on electric vehicle usage would not have a tremendous impact. Currently, the population of electric vehicles in Indonesia is considered low; approximately 3,000 units. The figure did not make a significant result to reduce air pollution or fossil fuel consumption.

As for reducing the use of dirty fuel, the Indonesia Ministry of Environment and Forestry has issued a regulation numbered P.20 / MENLHK / SETJEN / KUM.1 / 3/2017. The regulation concerns quality standards for Motor Vehicle Exhaust Emissions for New Types of Category M, Category $\mathrm{N}$, and Category $\mathrm{O}$. In the regulation, fourwheeled vehicles, at least, require to utilize octane number fuel (RON) by 91 . The only fuel product in Indonesia that meets the requirement is pertamax with RON 92. However, the regulation did not work effectively due to price issues. Fuel with RON 88 is sold cheaper, only IDR 6,450 per liter, whereas RON 92 fuel is sold for IDR 9,000 per liter. Thus, the public preferred to use cheaper fuel than the clean one. Besides, high octane fuels are rare to find. Only eighteen percent of 5,768 gas stations in Indonesia provide high octane fuels for consumer. ${ }^{20}$

\section{CONCLUSION}

The Bali Governor acts number $45 \& 48$ of 2019 serve as the legal basis for EV infrastructure development. Simultaneously, to encourage people to switch their preferences to use EV since the island's air quality deteriorates over time. To stimulate the Bali island's eco-friendly atmosphere, PT Jasamarga Bali Tol, who manages Bali Mandara Toll Road (Nusa Dua - Ngurah Rai - Benoa), launched a Public Electric Vehicle Charging Station. A collaborative project with the State Electricity Company (PLN) and PT. Opintech Djojo Indo to support EV migration and the Green toll road concept. The Ministry of State-Owned Enterprises (BUMN) also requested PT Pertamina (Persero) to produce electric car batteries instead of only fossil fuels. For the electric vehicle battery concept, State-owned Minister Erick Thohir has negotiated with international battery manufacturers.

Private companies are also involved in promoting eco-friendly vehicles, such as Grab collaborated with Bali Main Distribution Unit (UID), Bali Province Transportation Agency, PT Pegadaian, Astra Honda Motor, and Panasonic. Meanwhile, the Japanese car manufacturer, Toyota, plans to develop the Electric Vehicle Smart Mobility project in Bali to support Nusa Dua, Bali's ecotourism ecosystem.

Although EV would help reduce air pollution, 
The Central Government must attentively inspect the electric vehicle power source. Hitherto, most power plants in Indonesia are coal-fired power stations (PLTU). To solely depend on electric vehicle usage would not have a tremendous impact. Currently, the population of electric vehicles in Indonesia is considered low; approximately 3,000 units. The figure did not make a significant result to reduce air pollution or fossil fuel consumption.

\section{REFERENCES:}

1. Triatmodjo, M., (2005), Implikasi Berlakunya Protokol Kyoto-1997 Terhadap Indonesia.

2. Dericioglu, C., Yirik, E., Unal, E., Cuma, M., and Tumay, M., (2018), A Review of Charging Technologies For Commercial Electric Vehicles, International Journal of Advances on Automotive and Technology, Vol 2, No 1, pp. 61-70.

3. A mardiatuti. Gubernur Bali Terbitkan Peraturan Kendaraan Listrik. detikOto. 2019. Available at URL: https://oto.detik.com/berita/d-4781493/gubernur-baliterbitkan-peraturan-kendaraan-listrik? single $=1$.

4. A Aryanto. Pencemaran Udara Bali Makin Tinggi, Pertamina Kampanyekan Ini. wartaekonomi. 2020. Available at URL: https://www.wartaekonomi.co.id/ read293455/pencemaran-udara-bali-makin-tinggipertamina-kampanyekan-ini.

5. Winatha. Kualitas Udara Pengaruhi Pariwisata, Bali Bisa Ditinggalkan. Bali Post. 2019. Available at URL: https:// www.balipost.com/news/2019/04/24/73762/KualitasUdara-Pengaruhi-Pariwisata,Bali...html.

6. Illustration from dreamstime[dot]com 'Energy Sources'. Available at URL: https://www.dreamstime.com/energysources-vector-illustration-collection-infographic-otherenvironment-related-content-graphical-assets-renewableversus-image173736392\#.

7. Anonymous. Types of renewable energy. edfenergy. Available at URL: https://www.edfenergy.com/for-home/ energywise/renewable-energy-sources.

8. Anonymous. Pabrik Kendaraan Listrik di Jembrana Masuk FS Tol Denpasar-Gilimanuk Dimulai Maret 2021. nusabali. 2020. Available at URL: https://www.nusabali. com/berita/78149/pabrik-kendaraan-listrik-di-jembranamasuk-fs.

9. D Sugianto. Kendaraan Listrik Masih Sedikit, Banyak 'SPBU Listrik' Nganggur. detikFinance. 2020. Available at URL: https://finance.detik.com/energi/d-5130694/ kendaraan-listrik-masih-sedikit-banyak-spbu-listriknganggur.
10. Image by F Yusuf. Antara. 2020. Available at URL: https:// www.validnews.id/Kebutuhan-SPKLU-Hanya-5--dariJumlah-Mobil-Listrik-rwl.

11. HB Alexander. Stasiun Pengisian Kendaraan Listrik Tol Bali Mandara Disambut Antusias. kompas[dot] com. 2020. Available at URL: https://properti.kompas. $\mathrm{com} / \mathrm{read} / 2020 / 02 / 25 / 122238421 /$ stasiun-pengisiankendaraan-listrik-tol-bali-mandara-disambut-antusias.

12. A Hidayat. Bali Mulai Ramah dengan Mobil Listrik. mobil123[dot]com. 2020. Available at URL: https://www. mobil123.com/berita/mobil-listrik-di-bali-kini-lebihmudah-mengisi-daya/58475.

13. Anonymous. Pertamina Bersiap untuk Produksi Baterai Mobil. tribun-bali[dot]com. 2020. Available at URL: https://bali.tribunnews.com/2020/09/29/pertaminabersiap-untuk-produksi-baterai-mobil-listrik.

14. Image by H Kashioka. Copyright:H.Kashioka (TennenGas). CC BY-SA 3.0. Available at URL: https://en.wikipedia. org/wiki/Electric_vehicle_battery.

15. A Umah. Ini Alasan Kenapa RI Gencar Pengembangan Kendaraan Listrik. CNBC. 2020. Available at URL: https://www.cnbcindonesia.com/news/202010051055114-191886/ini-alasan-kenapa-ri-gencar-pengembangankendaraan-listrik.

16. R Devita, Winatha. Uji Coba Bus Listrik Jadi Daya Tarik Wisatawan di Bali. Bali Post. 2020. Available at URL: https://www.balipost.com/news/2020/11/09/156689/UjiCoba-Bus-Listrik-Jadi...html.

17. Anonymous. 'Kembali Perkuat Ekosistem KBL, Grab Luncurkan 30 Motor Listrik di Bali. tribun-bali[dot]com. 2020. Available at URL: https://www.tribunnews.com/ techno/2020/12/02/kembali-perkuat-ekosistem-kbl-grabluncurkan-30-motor-listrik-di-bali.

18. L Huda. Triwulan I 2021, Toyota Berencana Rilis Pengembangan Ekowisata di Bali. Tempo. 2020. Available at URL: https://bisnis.tempo.co/read/1413473/triwulan-i2021-toyota-berencana-rilis-pengembangan-ekowisata-dibali/full\&view $=$ ok.

19. Image stock 'CELUKAN BAWANG' by Thomson Reuters Foundation (creative commons license). Available at URL: https://newsbeezer.com/Philippines/legal-battle-over-balicoal-power-plant-lights-indonesia-energy-dilemma/.

20. A Prasetyo. Infrastruktur Pengisian Daya Kendaraan Belum Cukup. Kompas. 2020. Available at URL: https:// bebas.kompas.id/baca/ekonomi/2020/12/13/infrastrukturpengisian-daya-kendaraan-belum-cukup/.

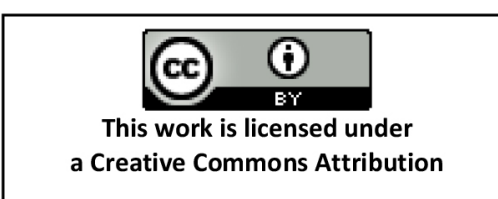

